\title{
Gold Coast Library Board
}

THE Gold Coast Library Board started in 1950. Nine libraries, with, in addition, four separate children's libraries, have been established throughout the country, and a stock of 130,000 books has been built up.

While the Library caters primarily for the reader who has been educated at school and who has reached a fairly high standard of literacy, the Library Board does in fact make a contribution to the spread of literacy at the higher level in the emphasis given to work with children. By providing attractive books and encouraging the reading habit at an age when it is easily acquired, a new generation of adult readers is assured. The aim is to foster an interest in reading in the school child, to deter him from slipping back into illiteracy when he leaves school.

In the rural areas, the number of potential library users is too few to warrant the establishment of permanent libraries, and these areas are therefore served by travelling libraties. Vans are specially constructed with shelving for 1,500 to 2,000 books, so arranged that readers can select their books from the vans. Books are loaned in boxes of 40 (for a subscription of $f^{2}$ per annum). In the year 1954- 5 more than 20,000 miles were covered and at the end of the year 20,650 books were on issue to readers through book boxes. Schools, clubs, community centres, firms, government agents' offices, police stations, as well as individuals take advantage of this service.

In addition to the travelling library service, readers in the rural areas may avail themselves of a postal service as country members at a subscription of ten shillings a year. Two books may be borrowed for a month at a time. The Library pays the postage one way, and the reader is responsible for return postage.

Books on all subjects are provided, as well as fiction, and every endeavour is made to meet special requests for particular books, or books on a particular subject. The bulk of the Gold Coast Library Board's stock consists of books in the English language. Although most books published in the vernacular are bought, the demand for them is very small, and the number issued to readers in rural areas from the library vans is negligible. It can only be assumed that the demand for vernacular literature is met mainly from other sources.

\section{Congress of Scholars of the Negro World}

A Congress, organized by Presence Africaine, is to be held in Paris from 19 to 22 September 1956 to which Negro writers, artists, and scholars from all countries are invited. The Congress will consider the contribution of Negroes to human culture, the relations to be established with the modern world, the themes, styles and forms most typical of the Negro genius, and methods of assisting young writers and artists and making their work more widely known. The Congress has the support of a number of well-known writers, artists, and scholars from West Africa, Martinique, Haiti and U.S.A. 